\title{
Motivation and Instructional Preference of EFL Students at Tertiary Level
}

\section{Dwi Ratnasari}

Universitas PGRI Palembang, Sumatera Selatan, Indonesia

Email of corresponding author: dwiratnasari@univpgri-palembang.ac.id

How to cite this paper: Ratnasari, D. (2019). Motivation and Instructional Preference of EFL Students at Tertiary Level. International Journal of Language Teaching and Education, 3 (1), 28-44. https://doi.org/10.22437/ijolte.v3i1.6559

Accepted: June 18, 2019

Published: July 31, 2019

Copyright (C) 2019 International Journal of Language Teaching and Education

This work is licensed under the Creative Commons Attribution International License (CC BY 4.0). http://creativecommons.org/license s/by/4.0/

\begin{abstract}
The aims of the study were to find out the relationship between students' motivation and instructional preference and to identify the main components of motivation that underlay the students to learn English and the students' most preferred instruction. This study is beneficial to contribute to teachers' understanding of the need to consider students' preferences when planning the teaching-learning activities and to choose the instructional methods to use in teaching. A mixed-method design was used in this study by combining quantitative and qualitative data to analyze. Descriptive statistics and interview analysis were used. The participants of this study were 323 students at a private university in Palembang, Indonesia. An 82-item questionnaire assessing motivation and instructional preference and semi-structured interview were used. The questionnaire consisted of 50 items measuring motivation and 32 items measuring instructional preference. The result showed that there was a positive and significant relationship between motivation and instructional preference. It means that students who had a higher level of motivation would have more instructional preferences than those who had a lower level of motivation. The result of the study also indicated that the primary motivational components underlying the students to learn English were instrumental orientation, intrinsic orientation, and integrative orientation, and the students' most preferred instruction was mastery learning. This study implies that teachers should be aware of diversifying the instructional methods used in their classes. They should take into account the students' characteristics when planning and implementing educational processes.
\end{abstract}

\section{Subject Areas}

Teaching English as a Foreign Language

\section{Keywords}

motivation, instructional preference, EFL students, tertiary level

\section{INTRODUCTION}

In countries where English is used as a foreign language (EFL), the chance to practice English with native speakers is almost unavailable to students. This seems to be the main factor which makes English challenging to learn (Ihsan and Diem, 1997). Due to this reason, it is difficult for EFL students to motivate themselves to learn English, a situation that Ryan $(2009,124)$ described as a "depressing 
picture." However, according to Chamot (1987), difficulties in learning English are not only actual for students who learn English as a foreign language (EFL), but also for those who learn English as a second language (ESL). Now, if this is the case, there must be factors besides the lack of native speakers that cause these problems in learning English.

According to Dardjowidjojo (1995, 2003), EFL teachers in Indonesia realize that many external factors commonly cause EFL students to fail in learning English. Among these are big classes, the geographical location of the schools, supplementary textbook availability especially in the library, access to a language laboratory, and teachers' qualifications (Alwi, 2000; Dardjowidjojo, 1995, 2003; Huda, 2000, Lauder, 2008; Renandya, 2000). Each of these conditions is related to the others and has made the problems of English teaching even more complicated for an individual EFL teacher to solve.

Personal characteristics, such as age, gender, aptitude, learning styles, personality, motivation, and language background, also influence students' success in EFL learning as Oxford (1994) said that students' characteristics need to consider when analyzing why English seems challenging to learn because an understanding of students' characteristics is crucial for a successful instruction in a second or foreign language. Parkay and Stanford (1992) also said that variables such as the teacher's personality and teaching style, the students' characteristics, the culture of the school and surrounding community, and the resources available influence instruction. These variables contribute to the models of instruction that teachers use in the classroom. Effective teaching demands that teachers must comprehend at least the students' age and gender as well as their motivation. Such knowledge will help teachers design and tailor the activities conducted in the classroom. Motivation is one of the students' characteristics is targeted by educators to advance learning. It provides the main impetus to start learning a language (Deci, Koester, and Ryan, 2001) and later becomes a driving force for maintaining a long and often dull learning process (Dornyei, 1998).

It does seem clear that understanding students' characteristics, such as motivation, helps teachers design the instruction. Teachers need to respond to individual differences in educational processes and adjust their activities to the students' characteristics, such as motivation. Therefore, there are links between motivation and pedagogical aspects of language teaching, such as instruction, that are also worth exploring.

However, in Indonesia, the profile of Indonesian students' motivation for learning English is not well researched. Likewise, "students' instructional preference" is still quite a vague concept to Indonesian EFL teachers although it can help them teach English more efficiently if they know and employ the instruction based on their students' preferences.

Therefore, this study, which mainly focused on one students' characteristic, that is motivation, sought to analyze the relationship between students' motivation and their instructional preference. Besides analyzing the relationship between motivation and instructional preference, this study also identified what motivated students to learn English and what the preferred instructional method of the students was. Instructional preference, in this study, is understood as an "individual's tendency to choose or express a preference for a specific teaching technique or combination of techniques" (Sadler-Smith, 1996:31). Thus, the objective was not to determine whether one method was better or not, but rather to understand the extent of students' preferences for a particular instructional method. 


\section{METHOD}

The central methodology used in this study was descriptive quantitative. This quantitative study aimed to investigate the relationship between students' motivation and their instructional preference and identify the main components of motivation, causing the students to learn English and the most preferred instructional model of the students. Also, qualitative data were obtained and used to gain broader perspectives on EFL students' motivation and instructional preference.

Descriptive statistics was used to describe the sample and to answer the research questions, and Rank Spearman correlation was used to analyze the quantitative data because the data obtained were ordinal (Santoso, 2000; Sarwono, 2006).

\subsection{Participants}

This study was carried out at English Education Study Program, Faculty of Teacher Training and Education, Universitas PGRI Palembang, Indonesia. The total number of the population can be seen in Table 1.

Table 1. Total Population

\begin{tabular}{ccc}
\hline No. & Semester & Number of Students \\
\hline 1. & I & 596 \\
2. & III & 501 \\
3. & V & 479 \\
4. & VII & 442 \\
\hline & Total & 2018 \\
\hline
\end{tabular}

Source: Faculty of Teacher Training and Education, Universitas PGRI Palembang, Academic Year 2009/2010

In this study, stratified random sampling was chosen since the population embraced several distinct categories, i.e., semester. A stratified random sampling allows the researcher to take into account the different subgroups of people in the population-based on specific characteristics (Jackson, 2008). All of the classes ranging from the first year to the fourth year of study were taken as the sample. Since there was only one academic session, the semesters taken for the sample were from semester I, III, V, and VII.

\subsection{Instrument}

The questionnaire used in this study was an adapted version of Schmidt, Boraie, and Kassabgy's instrument used in their study. A 103-item questionnaire was constructed, on which students indicated their agreement or disagreement with various statements on six-point Likert-scales (strongly disagree, disagree, slightly disagree, slightly agree, agree, and strongly agree). Six-point scales were used to eliminate neutral responses. The first 64 items of the questionnaire concerned motivation and the next set of 39 items concerned preference for classroom instructional activities.

The items on motivation, as suggested by Schmidt, Boraie, and Kassabgy (1996), were based on the theory of self-determination (Deci and Ryan, 1985; Feldman, 1989). However, some items, i.e. items concerning instrumental and integrative orientation, were added based on the theory of socioeducation (Adachi, 2009a, 2009b, 2010; Gardner, 1985, 1988, 2000, 2001; Gardner and MacIntyre, 1991, 1993), so that the wordings could precisely describe the EFL contexts in Indonesia. The items on instructional preference were also based on Schmidt, Boraie, and Kassabgy (1996). However, some items, i.e., items concerning mastery learning, theory into practice, behavior modification, and 
non-directive teaching, were added based on Parkay and Stanford's instructional models (1992).

\subsection{Validity and Reliability Analysis}

Before the questionnaire was administered to the sample of the study, it had been distributed to 40 students at another university in order to get its validity and reliability. The non-valid items are highlighted and can be seen in the Appendix.

From seven components of motivation, six components were valid and reliable since the $r$ coefficients of the components and the $\alpha$ coefficient $(\alpha=0.606)$ exceeded the $r$ table $(r=0.22)$. The six components are intrinsic orientation $(r=0.462)$, extrinsic orientation $(r=0.501)$, instrumental orientation $(r=0.653)$, integrative orientation $(r=0.836)$, attitudes towards Americans and British, and their culture $(r=0.628)$, and self-confidence $(r=0.578)$. The total number of items of these six components is 50 out of 64 items.

From nine models of instruction, seven models were valid and reliable since the $r$ coefficients of the models and the $\alpha$ coefficient $(\alpha=0.864)$ exceeded the $r$ table $(r=0.23)$. The seven models are balanced approach $(r=0.589)$, cooperative learning $(r=0.777)$, silent approach $(r=0.713)$, mastery learning $(r=0.495)$, theory into practice $(r=0.720)$, behavior modification $(r=0.634)$, and non-directive teaching $(r=0.646)$. The total number of items of these seven models is 32 out of 39 items.

\subsection{Quantitative Enquiry}

In order for the students to answer the questionnaire items seriously, the completion process of the questionnaire was conducted in a single class session. During the completion process, observation was conducted to monitor and to help the respondents to understand difficult parts. SPSS 16.0 package was used to analyze the data obtained from the questionnaire. By using a quantitative method, facts and data have an objective reality (Burns, 1997).

\subsection{Qualitative Enquiry}

For broader perspectives of students' motivation and their instructional preference, qualitative data analysis was also applied. A semi-structured group interview was conducted for qualitative inquiry. The rationale for choosing a semi-structured interview was because it permits greater flexibility than the close-ended type and permits a more valid response from the participants' perception of reality. In the semi-structured interview, a guide is developed for some parts of the interview in which, without fixed wording or fixed ordering of questions, a direction is given to the interview so that the content focuses on the crucial issues of the study (Burns, 1997). The rationale for using a group interview was because it allows participants to answer in any way they choose and to respond to each other (Jackson, 2008).

For the interview, six relevant questions were designed to elicit respondents' opinions on main issues concerning motivation and instructional preference. Eight students were selected on a random basis from the 323 students from different semesters, i.e., two students from each semester. The interview was conducted in four separate sessions with two students from the same semester in each session. In analyzing the qualitative data, an open coding method was used. The data was broken down and categorized into concepts. Then, it was carefully examined and compared for similarities and differences (O’Donoghue, 2007). 


\section{FINDINGS AND DISCUSSION}

\subsection{Relationships of Motivation and Models of Instruction}

One of the questions of this study aimed to investigate the relationship between motivation and instructional preference. In other words, this research question attempted to examine if the students who had a higher level of motivation would have more instructional preferences than those who had a lower level of motivation. The result obtained from the SPSS 16.0 computation for this relationship is shown in Table 2. It shows that the $r$ coefficient was 0.554. It can be inferred that there was a strong positive relationship between motivation and instructional preference since the $r$ coefficient was 0.554 (Table 2). In this case, the result of the study indicates that students having a higher level of motivation would have more instructional preferences than those having a lower level of motivation.

Table 2. Motivation and Instructional Preference

\begin{tabular}{|c|c|c|c|c|}
\hline & & & motivation & instruction \\
\hline \multirow[t]{6}{*}{ Spearman's rho } & motivation & Correlation Coefficient & 1.000 & $.554^{* *}$ \\
\hline & & Sig. (2-tailed) & . & .000 \\
\hline & & $\mathrm{N}$ & 323 & 323 \\
\hline & instruction & Correlation Coefficient & $.554^{* *}$ & 1.000 \\
\hline & & Sig. (2-tailed) & .000 & \\
\hline & & $\mathrm{N}$ & 323 & 323 \\
\hline
\end{tabular}

**. Relationship is significant at the 0.01 level (2-tailed).

In order to get a better understanding of students' motivation and their instructional preference, each aspect of the two variables was also analyzed. The aspects of motivation and instruction turned up many significant relationships, though not substantial in magnitude. Some of the relationships were moderate in magnitude (not greater than 0.500 ), and some others are weak in magnitude (not greater than 0.250) (Table 3).

The findings of this study showed that motivation and preference for instructional models were related. The correlation coefficient was positive and high, $r=0.554$, which means that the relationship between students' learning motivation and their preference for instructional models was strong. A study by Garcia-Ros, Perez, and Talaya (2008) also showed that there was a link between motivation and instructional preference. This study supports the findings of the previous studies (Schmidt, Boraie, and Kassabgy, 1996; Schmidt and Watanabe, 2001) which demonstrated that students who had a higher level of motivation would have more instructional preferences than those who had a lower level of motivation. 
Table 3. Relationships among Components of Motivation and Models of Instruction

\begin{tabular}{|c|c|c|c|c|c|c|c|c|}
\hline & & $\begin{array}{l}\text { balanced } \\
\text { approach }\end{array}$ & $\begin{array}{l}\text { cooperative } \\
\text { learning }\end{array}$ & $\begin{array}{c}\text { silent } \\
\text { approach }\end{array}$ & $\begin{array}{l}\text { mastery } \\
\text { learning }\end{array}$ & $\begin{array}{l}\text { theory } \\
\text { into prac- } \\
\text { tice }\end{array}$ & $\begin{array}{l}\text { behavior } \\
\text { modification }\end{array}$ & $\begin{array}{l}\text { non-directive } \\
\text { teaching }\end{array}$ \\
\hline \multirow{2}{*}{$\begin{array}{l}r \quad \text { coefficient } \\
\text { sig. }(2 \text {-tailed })\end{array}$} & intrinsic & $.270^{* *}$ & .011 & $-.184^{* *}$ & $.196^{* *}$ & $.268^{* *}$ & $.316^{* *}$ & $.262^{* *}$ \\
\hline & orientation & .000 & .843 & .001 & .000 & .000 & .000 & .000 \\
\hline \multirow{2}{*}{$\begin{array}{l}r \text { coefficient } \\
\text { sig. }(2 \text {-tailed })\end{array}$} & extrinsic & $-.145^{* *}$ & $.174^{* *}$ & $.366^{* *}$ & .044 & -.019 & -.061 & -.010 \\
\hline & orientation & .009 & .002 & .000 & .431 & .732 & .274 & .860 \\
\hline \multirow{2}{*}{$\begin{array}{l}r \text { coefficient } \\
\text { sig. }(2 \text {-tailed })\end{array}$} & instrumental & $.456^{* *}$ & $.144^{* *}$ & -.070 & $.447^{* *}$ & $.475^{* *}$ & $.391^{* *}$ & $.488^{* *}$ \\
\hline & orientation & .000 & .010 & .207 & .000 & .000 & .000 & .000 \\
\hline \multirow{2}{*}{$\begin{array}{l}r \text { coefficient } \\
\text { sig. }(2 \text {-tailed })\end{array}$} & integratve & $.242^{* *}$ & $.174^{* *}$ & .036 & $.302^{* *}$ & $.348^{* *}$ & $.373^{* *}$ & $.339^{* *}$ \\
\hline & orientation & .000 & .002 & .517 & .000 & .000 & .000 & .000 \\
\hline \multirow{2}{*}{$\begin{array}{l}r \text { coefficient } \\
\text { sig. }(2 \text {-tailed })\end{array}$} & attitudes & $.155^{* *}$ & $.230^{* *}$ & $.122^{*}$ & $.230^{* *}$ & $.206^{* *}$ & $.234^{* *}$ & $.228^{* *}$ \\
\hline & & .005 & .000 & .028 & .000 & .000 & .000 & .000 \\
\hline \multirow{2}{*}{$\begin{array}{l}r \text { coefficient } \\
\text { sig. }(2 \text {-tailed })\end{array}$} & self-confidence & $.165^{* *}$ & $.354^{* *}$ & .074 & $.179^{* *}$ & $.136^{*}$ & $.231^{* *}$ & $.127^{*}$ \\
\hline & & .003 & .000 & .186 & .001 & .014 & .000 & .022 \\
\hline
\end{tabular}

**. Relationship is significant at the 0.01 level (2-tailed).

Furthermore, relationships among aspects of motivation and instruction turned up numerous significant relationships. Students who were intrinsically, instrumentally, and integratively motivated preferred the same types of instruction: first, theory into practice, i.e., an instructional model where the teacher orients students to the materials to learn. i.e., tells students what they will learn and why it is crucial, presents new materials that consist of knowledge, skills, or processes that students are to learn, models what students are expected to do, checks for students' understanding, gives students opportunity for practice under guidance, and makes assignments that give students chance to practice what they have learned on their own; second, behavior modification, i.e., an instructional model where the teacher begins the lesson by presenting stimulus, observes students' behaviors, and reinforces appropriate behaviors as quickly as possible; and third, non-directive teaching, i.e. an instructional model where the teacher acts as a facilitator of learning, creates learning environments that support personal growth and development, and acts in the role of a counselor who helps students to understand themselves, clarify their goals, and accept responsibility for their behavior (Parkay and Standford, 1992).

While intrinsically motivated students preferred a balanced approach where listening, speaking, reading, and writing skill are taught equally in class, instrumentally motivated students preferred both balanced approach and mastery learning. However, integratively motivated students only preferred mastery learning, i.e. an instructional model where the teacher sets objectives and standards for mastery in English, teaches English directly to students, follows cycle of teaching, testing, re-teaching, and re-testing, provides additional help in correcting errors, and provides corrective feedback on students' learning (Parkay and Stanford, 1992). Facilitative feedback, primarily focusing on organizational aspects, can have a positive effect (Boramy, 2010). It is interesting to note that when the learner's peers initiate directive feedback, it also seems to have a positive effect on the learner's motivation levels (Hirose, 2012; Miyazoe \& Anderson, 2010).

On the other hand, students who were extrinsically motivated preferred silent approach where the teacher does most of the talking and the students only answer when they are called upon. In other words, these students prefer to sit and listen and do not like being forced to speak in class. They also think that communication activities are a waste of time in class.

Contrary to extrinsically motivated students, students who had self-confidence in learning English preferred cooperative learning in which the activities allow students to work together in pairs or small groups ( 4 to 6 students), the teacher gives assignments that require students help each 
other while working on a group project, and the group members contribute to group goals according to their talents, interests, and abilities (Parkay and Standford, 1992).

Although the motivational components and the instructional models used in this study were not entirely the same as those in Schmidt, Boraie, and Kassabgy's study (1996), this study has successfully proven that students might prefer different learning structures depending on the motivational components they possessed. Results of Schmidt, Boraie, and Kassabgy's study (1996) showed that intrinsically motivated students who expected to succeed showed a preference for a balanced approach in the foreign language classroom, appreciated challenging exercises and activities that encouraged their curiosity, even if they were not easy. On the other hand, students who scored high on the anxiety component would instead not participate actively in class and preferred to be silent. Students who scored high on intrinsic orientation indicated a preference for activities that allowed them to participate actively and that would help them to improve their ability to communicate, including, group and pair work, while students who scored low on intrinsic orientation and high on anxiety factor rejected group activities, pair work, and other communicative activities, and preferred to be silent and work alone.

\subsection{Motivation in Learning English as a Foreign Language}

Table 4 shows the results for the descriptive statistics of motivation data which are listed based on ranking from the highest mean to the lowest one.

Table 4. Descriptive Statistics of Motivational Components

\begin{tabular}{lrrrr}
\hline & $\mathrm{N}$ & Minimum & Maximum & Mean \\
\hline instrumental orientation & 323 & 1.272 & 6.000 & 5.072 \\
intrinsic orientation & 323 & 2.416 & 5.916 & 4.978 \\
$\begin{array}{l}\text { integrative orientation } \\
\text { self-confidence }\end{array}$ & 323 & 1.222 & 6.000 & 4.468 \\
$\begin{array}{l}\text { attitudes towards Americans and } \\
\text { British }\end{array}$ & 323 & 2.428 & 6.000 & 4.339 \\
extrinsic orientation & 323 & 1.500 & 5.666 & 3.896 \\
\hline Valid N (listwise) & 323 & 1.000 & 5.200 & 2.981 \\
\hline
\end{tabular}

With reference to Table 4, the highest mean score of the motivational component for the sample of the study was instrumental orientation which was then followed by intrinsic orientation, integrative orientation, self-confidence, attitudes towards Americans and British, and extrinsic orientation. Therefore, the main components of motivation underlying the students to learn English were instrumental orientation, intrinsic orientation, and integrative orientation.

Reasons for Learning English

All students opined that English is learned for instrumental reasons, i.e., to be able to read and understand any sources of English, to become more knowledgeable and educated, to get a better job or financial benefits, to add their social status, and to have a marvelous life. However, along with instrumental reasons, four students identified intrinsic reasons; and three students identified integrative reasons, i.e., to communicate and make friends from other countries, and to spend a period in an English speaking country. Only one student identified extrinsic reasons along with instrumental reasons, i.e., to show her ability to her family and friend. 


\section{Possibility of Going Abroad to Learn English}

Six students considered going overseas to learn English. However, the remaining two suggested to study in their home country because there were still many competent teachers; besides, the government could invite native speakers to teach in their home country.

Anxiety When Learning English

Five students, when asked whether they felt anxious when learning English, expressed their confidence with their English. However, one male student sometimes felt anxious, but tried to relax when the anxiety came; and the other ones felt anxious or did not have self-confidence when learning English.

From the data, the results of the study indicated that the primary motivational components that underlay the students to learn English were instrumental orientation $(\mu=5.072)$, intrinsic orientation $(\mu=4.978)$, and integrative orientation $(\mu=4.468)$. These quantitative results were consistent with the qualitative results on motivation. In qualitative results, the main motivational components were also instrumental orientation, intrinsic orientation, and integrative orientation. Both these quantitative and qualitative findings were consistent with the findings of Kimura, Nakata, and Okumura's study (2000), who suggested that the main components of language learning motivation observed in EFL context were complex, consisting of intrinsic, integrative, and instrumental components. Rahman's study (2005) also demonstrated that instrumental orientation was the main motivational component for the students to learn English.

The first two motivational components of this study (i.e., instrumental and intrinsic orientation) were also consistent with the first two motivational components found in Schmidt, Boraie, and Kassabgy's study (1996). However, integrative orientation, as the third motivational component in this study, was not found in their study. Instead, they found that extrinsic orientation was the third motivational component of the students to learn English.

\subsection{Instructional Preference in Learning English as a Foreign Language}

The results for the descriptive statistics of instructional preference data are listed based on ranking from the highest mean to the lowest one (Table 5). 
Table 5. Descriptive Statistics of Instructional Models

\begin{tabular}{lllll}
\hline & $\mathrm{N}$ & Minimum & Maximum & Mean \\
\hline mastery learning & 323 & 2.600 & 6.000 & 5.149 \\
non-directive teaching & 323 & 1.250 & 6.000 & 5.109 \\
theory into practice & 323 & 2.833 & 6.000 & 4.944 \\
behavior modification & 323 & 1.666 & 6.000 & 4.784 \\
balanced approach & 323 & 1.000 & 6.000 & 4.739 \\
cooperative learning & 323 & 1.250 & 5.750 & 4.151 \\
silent approach & 323 & 1.000 & 6.000 & 3.107 \\
\hline
\end{tabular}

Valid N (listwise)

323

With reference to Table 5, the highest mean score of the instructional model for the sample of the study was mastery learning which was then followed by non-directive teaching, theory into practice, behavior modification, balanced approach, cooperative learning, and silent approach. Therefore, the most preferred instruction of the students was mastery learning.

Ways of Teaching to Overcome Students' Anxiety in Learning English

Four students suggested non-directive teaching, i.e., an instructional model where the teacher understands what the students want, acts as a facilitator of learning, creates opportunities for students to improve their self-understanding and self-concepts, and involves the students in a teaching-learning partnership. Two students suggested behavior modification, i.e., an instructional method where the teacher begins the lesson by presenting stimulus, observes students' behaviors, and reinforces appropriate behaviors as quickly as possible. However, only one student suggested theory into practice, i.e., an instructional model where the teacher orients students to the lesson to be learned and allows students to practice what they have learned. The other one suggested mastery learning, i.e., an instructional model where the teacher sets objectives and standards for mastery in English; follows the cycle of teaching, testing, re-teaching, and re-testing; gives immediate corrective feedback to students on their learning, so that the students know whether their responses are right or wrong, but does not criticize students who make mistakes in class; and provides additional time and help in correcting errors.

\section{Ways of Teaching to Improve Students' English Proficiency}

When asked to identify ways of teaching to improve students' English proficiency, three students suggested theory into practice. Other three students suggested non-directive teaching. One student suggested mastery learning. The other one suggested cooperative learning, i.e., an instructional model where students work together in pairs or small groups, do discussion and presentation, do communicative and interactive activities. 


\section{Instructional Preference}

When asked to identify the instruction they prefer, four students chose theory into practice. Other two students chose non-directive teaching. One student chose mastery learning, and the other one chose a balanced approach.

The results of the study indicated that the most preferred instruction of Indonesian EFL students was mastery learning $(\mu=5.149)$. Mastery learning is also believed by some researchers (e.g., Gentile and Lalley, 2003; Guskey, 1997) to be the students' most preferred instructional model. Besides, Parkay and Stanford (1992) said that mastery learning is an outstanding system of the instructional model because it uses diagnostic progress testing and feedback with correction procedures. Mastery learning, first set by Benjamin S. Bloom in the late 1960s, is developed as a way for teachers to provide higher quality and more appropriate instruction for their students (Guskey, 1997). It helps teachers provide a higher quality of instruction for more of their students. Bloom (1974) outlined two important procedures in mastery learning, i.e., providing students with regular feedback on their learning progress, and pairing that feedback with specific corrective activities designed to help students remedy their individual learning difficulties. Bloom further mentioned that there are two essential elements in mastery learning. The first is feedback, corrective, and enrichment process. The second is congruence among instructional components. These two elements show that mastery learning is both flexible and broad in its applications, and, as a result, highly appealing to teachers at all levels. Mastery learning is usually implemented through a careful process of organization and planning, followed by specific procedures for classroom application and student assessment or evaluation. Mastery learning offers a useful instructional tool that can be flexibly applied in a variety of teaching situations.

Based on these results, we can assert that the underlying structure of preference for instructional methodology is articulated around four characteristics identified by Parkay and Stanford (1992): (1) the objectives and standards for mastery; (2) the cycle of teaching, testing, reteaching, and retesting; (3) the provision of corrective feedback to students on their learning; and (4) the provision of additional time and help in correcting students' errors.

However, the results of the qualitative data showed that the students' most preferred instruction was theory into practice. Mastery learning, the most preferred instruction in quantitative findings, was ranked in qualitative findings as the third preferred instruction after non-directive teaching. The different findings between the quantitative and qualitative data might be because the students selected for the interview were chosen randomly from the entire sample.

\section{CONCLUSIONS}

Motivation plays a crucial role in learning a language. It is not only important in getting students to engage in academic activities but also crucial in determining the instruction conducted in the classroom (Oxford, 1994). That is why good teachers have to understand students' motivation because an understanding of students' motivation is critical for successful instruction in a second or foreign language. Effective teaching demands that teachers must comprehend students' characteristics, at least students' motivation. Such knowledge helps teachers design and tailor the 
activities conducted in the classroom. Parkay and Stanford (1992) also said that students' motivation influence instruction. Their motivation contributes to the model of instruction the teachers use in the classroom. The findings of this study have successfully underlined the needs to consider students' motivation when planning and implementing educational instruction.

The findings from the study of Indonesian EFL students support several conclusions which have been made about language learning motivation and instructional preference. The results of the study indicated that there was a positive, strong, and significant relationship between motivation and instructional preference. Students who had a higher level of motivation would have more instructional preferences than those who had a lower level of motivation.

The quantitative data as the primary source of this study also clearly indicated that the main motivational component that underlay the students to learn English was instrumental orientation. What had been defined as intrinsic and integrative motivation in the ESL context was also found to be the second and the third main motivational component among EFL students.

About instructional preference, the quantitative data also clearly indicated that the students were inclined towards mastery learning model of instruction. By contrast, the silent approach came to be the least-valued method. Also, as found in this study, students who had a higher level of motivation would have more instructional preferences. Therefore, teachers should be aware of diversifying the instructional models used in their classes because students can become more experienced and capable students when interacting with diverse models of instruction (Check, 1984; Entwistle and Peterson, 2005; Loo, 2004; Sadler-Smith and Smith, 2004). Diversifying instructional models in university education is crucial. Facilitating different instructional models encourages the development of teaching skills for the choice and adaptation of teaching methodologies which are best suited to the individual characteristics of the students (Garcia-Ros, Perez, and Talaya, 2008). It is also suggested that when learners enjoy positive experiences of their preference, they are more likely to take control of their language learning and become independent (Lee, 2010).

\section{References}

[1] Adachi, R. (2009a). Age-related differences regarding motivation and orientation of young Japanese EFL learners. Language Education and Technology Journal of Central Japan, 20, 21- 34.

[2] Adachi, R. (2009b). Motivation of young Japanese EFL learners and effect factors. JASTEC Journal, 28, 43-64.

[3] Adachi, R. (2010). A structural equation model of motivation and attitudes of young Japanese foreign language learners. Language Education and Technology Journal of Central Japan, 47, 205-226.

[4] Alwi, H. (2000). Fungsi politik bahasa. In H. Alwa \& D. Sugono (Eds.), Politik bahasa: Risalah seminar politik bahasa, 6-20. Jakarta: Pusat Bahasa dan Departemen Pendidikan Nasional.

[5] Bloom, B. S. (1974). An introduction to mastery learning theory. In J. H. Block (Ed.), Schools, society, and mastery learning (pp. 3-14). New York: Holt, Rinehart \& Winston.

[6] Boramy, S. (2010). Using directive and facilitative feedback to improve student writing: A case study of a higher education setting in Cambodia. Language Education in Asia, 1(1), 23-47.

[7] Burns, R. B. (1997). Introduction to research methods (3rd ed.). Sydney: Longman.

[8] Chamot, A. U. (1987). The learning-style inventory (Revised by Evelyn C. Davis, 1994). English Teaching Forum, July 1974, 16-17. 
[9] Check, J. F. (1984). Teaching learning preference of the adult learner. Education, 105, 107-112.

[10] Dardjowidjojo, S. (1995). The socio-political aspects of English in Indonesia. Paper presented in the TEFLIN Silver Anniversary Seminar at IKIP Yogyakarta, Universitas and Universitas Sanata Darma, August 2-5, 1995.

[11] Dardjowidjojo, S. (2003). English teaching: Where and how do we begin? In K. E. Sukamto (Ed.), Rampai bahasa, pendidikan, dan budaya: Kumpulan esai Soenjono Dardjowidjojo (pp. 29-40). Jakarta: Yayasan Obor, Indonesia.

[12] Deci, E., Koester, R., \& Ryan, R.M. (2001). Extrinsic rewards and intrinsic motivation in education: Reconsidered once again. Review of Education Research, 71(1), 1-27.

[13] Deci, E. L. \& Ryan, R. M. (1985). Intrinsic motivation and self-determination in human behavior. New York: Plenum Press.

[14] Dornyei, Z. (1998). Motivation in second language learning. Language Teaching, 31, 117-135

[15] Entwistle, N. \& Peterson, E. R. (2005). Conceptions of learning and knowledge in higher education: Relationships with study behavior and influences of learning environments. International Journal of Educational Research, 41, 407-428.

[16] Feldman, R. S. (1989). Essentials of understanding psychology. New York: McGraw-Hill Book Company.

[17] Garcia-Ros, R., Perez, F., \& Talaya, I. (2008). New university students' instructional preference and how these relate to learning styles and motivational strategies. Electronic Journal of Research in Educational Psychology, 6(3), 547570. Retrieved September 8, 2009, from http://www.investigation-psicopedagogica.org/revista/articulos/16/english/Art 16 230.pdf

[18] Gardner, R. C. (1985). Social psychology and second language learning: The role of attitudes and motivation. London: Edward Arnold.

[19] Gardner, R. C. (1988). The socio-educational model of second-language learning: assumptions, findings, and issues. Language Learning, 38, 101-126.

[20] Gardner, R. C. (2000). Relationship, causation, motivation, and second language acquisition. Canadian Psychology, 41, 1-24.

[21] Gardner, R. C. (2001). Integrative motivation and second language acquisition. In Z. Dornyei \& R. Schmidt (Eds.), Motivation and second language acquisition (pp. 1-19). Honolulu: University of Hawai'i, Second Language Teaching \& Curriculum Center.

[22] Gardner, R. C. \& MacIntyre, P. D. (1991). An instrumental motivation in language study: Who says it isn't effective? Studies in Second Language Acquisition, 13, 57-72.

[23] Gardner, R. C. \& MacIntyre, P. D. (1993). A student's contributions to second language learning. Part II: Affective variables. Language Teaching, 26, 218-233.

[24] Gentile, J. R. \& Lalley, J. P. (2003). Standards and mastery learning: Aligning teaching and assessment so all children can learn. California: Corwin Press, Inc.

[25] Guskey, T. R. (1997). Implementing mastery learning. Belmont: Wadsworth Publishing Company.

[26] Hirose, K. (2012). Written feedback and oral interaction: How bimodal peer feedback affects Japanese EFL students. The Journal of Asia TEFL, 9(3), pp 1-26. i-Talk-i. (n.d.). Retrieved December 30, 2013, from http://www.italki.com/

[27] Huda, N. (2000). Kedudukan dan fungsi Bahasa asing (The position and function of a foreign language). In H. Alwi \& D. Sugono (Eds.), Politik Bahasa: Risalah seminar politik bahasa (Language politics: Proceedings of the seminar on language politics) (pp. 59-78). Jakarta: Pusat Bahasa dan Departemen Pendidikan Nasional.

[28] Ihsan, D. \& Diem, C. D. (1997). The learning styles and language learning strategies of the EFL students at the tertiary level. Jurnal IImu Pendidikan, 4, 319-332.

[29] Jackson, S. H. (2008). Research methods: A modular approach. Australia: Thomson Wadsworth.

[30] Kimura, Y., Nakata, Y., \& Okumura, T. (2000). Language learning motivation of EFL students in Japan: A cross-sec- 
tional analysis of various learning milieus. JALT Journal, 47-65. Retrieved July 16, 2009, from http://www.jalt-publications.org/archive/ii/2001a/art3.pdf

[31] Lauder, A. (2008). The status and function of English in Indonesia: A review of key factors. Makara, Sosial Humaniora, 12(1), 9-20.

[32] Lee, L. (2010). Fostering reflective writing and interactive exchange through blogging in an advanced language course. ReCALL, 22(2), 212-227.

[33] Loo, R. (2004). Kolb's learning styles and learning preference: Is there a linkage? Educational Psychology, 24(1), 99108.

[34] Miyazoe, T. \& Anderson, T. (2010). Learning outcomes and students' perceptions of online writing: Simultaneous implementation of a forum, blog, and wiki in an EFL blended learning setting. System, 38(2), 185-199.

[35] O'Donoghue, T. (2007). Planning your qualitative research project: An introduction to interpretivist research in education. London: Routledge.

[36] Oxford, R. L. (1994). Variables, individual in language learning: Classroom implications. In R. E. Asher \& J. M. Y. Simpson (Eds.), The Encyclopedia of language and linguistic (Vol. 9, pp. 4893-4899). Oxford: Pergamon Press.

[37] Parkay, F. W. \& Stanford, B. H. (1992). Becoming a teacher: Accepting the challenge of a profession (2nd ed.). Boston, MA: Allyn and Bacon.

[38] Rahman, S. (2005). Orientations and motivation in English language learning: A study of Bangladeshi students at undergraduate level. The Asian EFL Journal Quarterly, 7(1), 29-55. Retrieved July 16, 2009, from http://www.asianefl-journal.com/march 2005 sr.php

[39] Renandya, W. A. (2000). Indonesia. In Wah Kam Ho \& Ruth Y. L. Wong (Eds.), Language policies and language education: The impact in East Asian countries in the next decade (pp. 113-137). Singapore: Times Academic Press.

[40] Ryan, S. (2009). Self and identity in L2 motivation in Japan: The ideal L2 self and Japanese learners of English. In Z. Dörnyei \& E. Uhioda (Eds.), Motivation, language identity, and the L2 Self (pp.120-143). Clevedon, UK: Multilingual Matters.

[41] Sadler-Smith, E. (1996). Learning styles: A holistic approach. Journal of European Industrial Training, 20, 29-36.

[42] Sadler-Smith, E. \& Smith, P. J. (2004). Strategies for accommodating individuals' styles and preference in flexible learning programmes. British Journal of Educational Technology, 35(4), 395-412.

[43] Santoso, S. (2000). Buku latihan SPSS statistik parametrik. Jakarta: PT Elex Media Komputindo.

[44] Sarwono, J. (2006). Analisis data penelitian menggunakan SPSS 13. Yogyakarta: CV Andi Offset

[45] Schmidt, R., Boraie, D., \& Kassabgy, O. (1996). Foreign language motivation: Internal structure and external connections. In J. D. Brown (Ed.), University of Hawai'i working papers in ESL, 14(2), 1-71.

[46] Schmidt, R. \& Watanabe, Y. (2001). Motivation, strategy use and pedagogical preference in foreign language learning. In Z. Dörnyei \& R. Schmidt (Eds.), Motivation and second language acquisition. Honolulu: University of Hawai'i Second Language Teaching and Curriculum Center. 


\section{Appendix}

\section{QUESTIONNAIRE}

Semester :

\section{Directions:}

$>$ Read the following statements carefully.

$>$ Respond the statements honestly based on your own opinion by giving a tick $(\sqrt{ })$ on one of six answer choices (STD, D, SLD, SLA, A, or STA).

$>$ Before you hand in this questionnaire, please make sure that there is no statement that has not been answered yet.

$>$ Thank you for your participation.

\section{Part A. Motivation}

\begin{tabular}{|c|c|c|c|c|c|c|c|}
\hline No. & $\begin{array}{ll}\text { Strongly Disagree (STD) } & \text { Slightly Agree (SLA) } \\
\text { Disagree(D) } & \text { Agree (A) } \\
\text { Slightly Disagree (SLD) } & \text { Strongly Agree (STA) }\end{array}$ & $\begin{array}{l}\text { STD } \\
(1)\end{array}$ & $\begin{array}{c}\text { D } \\
\text { (2) }\end{array}$ & $\begin{array}{l}\text { SLD } \\
\text { (3) }\end{array}$ & $\begin{array}{l}\text { SLA } \\
\text { (4) }\end{array}$ & $\begin{array}{c}A \\
\text { (5) }\end{array}$ & $\begin{array}{l}\text { STA } \\
(6)\end{array}$ \\
\hline & \multicolumn{7}{|l|}{ Intrinsic orientation } \\
\hline 1. & I enjoy learning English very much. & & & & & & \\
\hline 2. & Learning English is a hobby for me. & & & & & & \\
\hline 3. & Learning English is a challenge that I enjoy. & & & & & & \\
\hline 4. & $\begin{array}{l}\text { If the fees for the English program were increased, I would still enroll } \\
\text { because studying English is important for me. }\end{array}$ & & & & & & \\
\hline 5. & My attendance in the class will be good. & & & & & & \\
\hline 6. & I plan to continue studying English for as long as I can. & & & & & & \\
\hline 7. & $\begin{array}{l}\text { After I graduate, I will probably continue studying English to a higher } \\
\text { degree. }\end{array}$ & & & & & & \\
\hline 8. & I often think about how I can learn English better. & & & & & & \\
\hline 9. & $\begin{array}{l}\text { I can honestly say that I really put my best effort into trying to learn } \\
\text { English. }\end{array}$ & & & & & & \\
\hline 10. & Studying English is fun. & & & & & & \\
\hline 11. & Even if there were no homework, I would try to study outside of the class. & & & & & & \\
\hline 12. & I like studying English. & & & & & & \\
\hline \multirow[t]{2}{*}{13.} & $\begin{array}{l}\text { I really want to learn more English in this program than I have done in } \\
\text { high school. }\end{array}$ & & & & & & \\
\hline & \multicolumn{7}{|l|}{ Extrinsic orientation } \\
\hline 14. & Studying English is a waste of time. & & & & & & \\
\hline 15. & $\begin{array}{l}\text { I do not enjoy learning English, but I know that learning English is } \\
\text { important for me. }\end{array}$ & & & & & & \\
\hline 16. & I wish I could learn English in an easier way, without going to class. & & & & & & \\
\hline 17. & $\begin{array}{l}\text { The main reason I am taking English program is that my } \\
\text { parents/spouse/employer want me to improve my English }\end{array}$ & & & & & & \\
\hline 18. & $\begin{array}{l}\text { I want to do well in English because it is important to show my ability to my } \\
\text { family/employer/friends/others. }\end{array}$ & & & & & & \\
\hline 19. & It is important for me to do better than other students in my class. & & & & & & \\
\hline 20. & My relationship with the teacher in the class is important for me. & & & & & & \\
\hline 21. & $\begin{array}{l}\text { One of the most important things in the class is getting along with other } \\
\text { students. }\end{array}$ & & & & & & \\
\hline 22. & I put off doing my homework/assignment until right before the due date. & & & & & & \\
\hline & Instrumental orientation & & & & & & \\
\hline 23. & English is important for me because it will broaden my view. & & & & & & \\
\hline 24. & Being able to speak English will add to my social status. & & & & & & \\
\hline 25. & I am learning English to become more educated. & & & & & & \\
\hline 26. & $\begin{array}{l}\text { I need to be able to read/understand books/magazines/newspapers/ } \\
\text { novels/movies in English. }\end{array}$ & & & & & & \\
\hline 27. & If I learn English better, I will be able to get a better job. & & & & & & \\
\hline 28. & Increasing my English proficiency will have financial benefits for me. & & & & & & \\
\hline 29. & If I can speak English, I will have a marvelous life. & & & & & & \\
\hline 30. & English is important for me because it will make me more knowledgeable. & & & & & & \\
\hline 31. & $\begin{array}{l}\text { English will be useful for me in getting a good and high-ranking job in } \\
\text { Indonesia. }\end{array}$ & & & & & & \\
\hline
\end{tabular}




\begin{tabular}{|c|c|c|c|c|c|c|c|}
\hline No. & $\begin{array}{ll}\text { Strongly Disagree (STD) } & \text { Slightly Agree (SLA) } \\
\text { Disagree(D) } & \text { Agree (A) } \\
\text { Slightly Disagree (SLD) } & \text { Strongly Agree (STA) }\end{array}$ & $\begin{array}{l}\text { STD } \\
(1)\end{array}$ & $\begin{array}{c}D \\
(2)\end{array}$ & $\begin{array}{l}\text { SLD } \\
(3)\end{array}$ & $\begin{array}{l}\text { SLA } \\
(4)\end{array}$ & $\begin{array}{c}A \\
(5)\end{array}$ & $\begin{array}{c}\text { STA } \\
(6)\end{array}$ \\
\hline 32. & I study English because I want to be an English teacher. & & & & & & \\
\hline \multirow[t]{2}{*}{33.} & $\begin{array}{l}\text { English class is important for me because if I learn English well, I will be } \\
\text { able to help my children learn English. }\end{array}$ & & & & & & \\
\hline & Integrative orientation & & & & & & \\
\hline 34. & $\begin{array}{l}\text { I am learning English because I want to spend a period of time in an } \\
\text { English speaking country. }\end{array}$ & & & & & & \\
\hline 35. & $\begin{array}{l}\text { I want to learn English because it is useful when travelling in many } \\
\text { countries. }\end{array}$ & & & & & & \\
\hline 36. & $\begin{array}{l}\text { I want to learn English because I would like to emigrate to an English } \\
\text { speaking country. }\end{array}$ & & & & & & \\
\hline 37. & English helps me to think and behave like English native speakers. & & & & & & \\
\hline 38. & I would like to make British/American friends. & & & & & & \\
\hline 39. & $\begin{array}{l}\text { I would like to communicate with people in other English speaking } \\
\text { countries. }\end{array}$ & & & & & & \\
\hline 40. & I am studying English because I would like to live abroad in the future. & & & & & & \\
\hline 41. & $\begin{array}{l}\text { English will help me to better understand the English native speakers and } \\
\text { their ways of life. }\end{array}$ & & & & & & \\
\hline \multirow[t]{2}{*}{42.} & I really like to emulate/imitate the English native speakers. & & & & & & \\
\hline & Expectation of success & & & & & & \\
\hline 43. & English class will definitely help me improve my English. & & & & & & \\
\hline 44. & I expect to do well in the class because I am good at learning English. & & & & & & \\
\hline 45. & If I do well in the class, it will be because I try hard. & & & & & & \\
\hline 46. & If I do not do well in the class, it will be because I do not try hard enough. & & & & & & \\
\hline 47. & $\begin{array}{l}\text { If I do not do well in the class, it will be because I do not have much ability } \\
\text { for learning English. }\end{array}$ & & & & & & \\
\hline 48. & If I learn a lot in the class, it will be because of the teacher. & & & & & & \\
\hline 49. & If I do well in the class, it will be because this is an easy class. & & & & & & \\
\hline 50. & If I do not learn well in the class, it will be mainly because of the teacher. & & & & & & \\
\hline \multirow[t]{2}{*}{51.} & If I do not do well in the class, it will be because the class is too difficult. & & & & & & \\
\hline & $\begin{array}{l}\text { Attitudes towards Americans \& British, } \\
\text { and their culture }\end{array}$ & & & & & & \\
\hline 52. & $\begin{array}{l}\text { British/Americans are conservative people who cherish/hold customs } \\
\text { and traditions. }\end{array}$ & & & & & & \\
\hline 53. & British/Americans are very friendly people. & & & & & & \\
\hline 54. & Most of my favourite actors and musicians are either British or Americans. & & & & & & \\
\hline 55. & British/American culture has contributed a lot to the world. & & & & & & \\
\hline 56. & I am interested in British/American lifestyles and cultures. & & & & & & \\
\hline \multirow[t]{2}{*}{57.} & I am interested in lives and cultures of English speaking countries. & & & & & & \\
\hline & Self-confidence & & & & & & \\
\hline 58. & I feel comfortable if I have to speak in my English class. & & & & & & \\
\hline 59. & It does not embarrass me to volunteer answer in English class. & & & & & & \\
\hline 60. & $\begin{array}{ll}\text { I like to speak often in English class because I am not afraid } & \text { that my } \\
\text { teacher will think I am not a good student. } & \\
\end{array}$ & & & & & & \\
\hline 61. & I am not afraid if other students will laugh at me when I speak English. & & & & & & \\
\hline 62. & I do not have difficulty concentrating in English class. & & & & & & \\
\hline 63. & $\begin{array}{l}\text { I think I can learn English well because I perform well on tests and } \\
\text { examinations. }\end{array}$ & & & & & & \\
\hline 64. & I am good at English. & & & & & & \\
\hline
\end{tabular}


Part B. Instructional Preference

\begin{tabular}{|c|c|c|c|c|c|c|c|}
\hline No. & $\begin{array}{ll}\text { Strongly Disagree (STD) } & \text { Slightly Agree (SLA) } \\
\text { Disagree(D) } & \text { Agree (A) } \\
\text { Slightly Disagree (SLD) } & \text { Strongly Agree (STA) }\end{array}$ & $\begin{array}{l}\text { STD } \\
(1)\end{array}$ & $\begin{array}{l}D \\
(2)\end{array}$ & $\begin{array}{l}\text { SLD } \\
(3)\end{array}$ & $\begin{array}{l}\text { SLA } \\
(4)\end{array}$ & $\begin{array}{c}\text { A } \\
(5)\end{array}$ & $\begin{array}{l}\text { STA } \\
(6)\end{array}$ \\
\hline & Balanced approach & & & & & & \\
\hline 1. & It is important for teacher to maintain discipline in English class. & & & & & & \\
\hline 2. & Teacher should make sure that everyone in the class learns English equally well. & & & & & & \\
\hline 3. & $\begin{array}{l}\text { Students should ask questions whenever they have not understood a point in } \\
\text { class. }\end{array}$ & & & & & & \\
\hline 4. & $\begin{array}{l}\text { Students should let the teacher know why they are studying English so that the } \\
\text { lessons can be made relevant to their goals. }\end{array}$ & & & & & & \\
\hline 5. & $\begin{array}{l}\text { Listening, speaking, reading, and writing should be taught equally in English } \\
\text { class. }\end{array}$ & & & & & & \\
\hline 6. & $\begin{array}{l}\text { Activities in this class should be designed to help students improve their ability } \\
\text { in English. }\end{array}$ & & & & & & \\
\hline & Cooperative learning & & & & & & \\
\hline 7. & $\begin{array}{l}\text { I like English learning activities in which students work together in pairs or } \\
\text { small groups. }\end{array}$ & & & & & & \\
\hline 8. & $\begin{array}{l}\text { Teacher should give assignments that require students help one another while } \\
\text { working on a group project. }\end{array}$ & & & & & & \\
\hline 9. & $\begin{array}{l}\text { I prefer to work by myself in English class, not with other students. (reverse } \\
\text { coded) }\end{array}$ & & & & & & \\
\hline 10. & $\begin{array}{l}\text { Pair works and group activities in English class are a waste of time. (reverse } \\
\text { coded) }\end{array}$ & & & & & & \\
\hline & Silent approach & & & & & & \\
\hline 11. & $\begin{array}{l}\text { In English class, teacher should do most of the talking and students should only } \\
\text { answer when they are called upon. }\end{array}$ & & & & & & \\
\hline 12. & I prefer to sit and listen, and do not like being forced to speak in class. & & & & & & \\
\hline 13. & $\begin{array}{l}\text { Communication activities are a waste of time in this class because I only need } \\
\text { to learn what is necessary for me. }\end{array}$ & & & & & & \\
\hline & Challenging approach & & & & & & \\
\hline 14. & I prefer activities and materials that really challenge me, so I can learn more. & & & & & & \\
\hline 15. & $\begin{array}{l}\text { I prefer activities and materials that arouse my curiosity even if it is difficult to } \\
\text { learn. }\end{array}$ & & & & & & \\
\hline 16. & I prefer a class with lots of activities that allow me to participate actively. & & & & & & \\
\hline & Directive teaching & & & & & & \\
\hline 17. & During class, I would like to have only English spoken. (reverse coded) & & & & & & \\
\hline 18. & $\begin{array}{l}\text { In my English class, teacher should explain things in Indonesian sometimes in } \\
\text { order to help us learn. }\end{array}$ & & & & & & \\
\hline 19. & English class is most useful when the emphasis is put on grammar. & & & & & & \\
\hline & Mastery learning & & & & & & \\
\hline 20. & Teacher should set objectives and standards for mastery in English. & & & & & & \\
\hline 21. & Teacher should teach the subject directly to students. & & & & & & \\
\hline 22. & Teacher should provide corrective feedback to students on their learning. & & & & & & \\
\hline 23. & Teacher should provide additional time and help in correcting errors. & & & & & & \\
\hline 24. & Teacher should follow cycle of teaching, testing, re-teaching, re-testing. & & & & & & \\
\hline 25. & $\begin{array}{l}\text { It is important for teacher to give immediate feedback, so that students know } \\
\text { whether their responses are right or wrong. }\end{array}$ & & & & & & \\
\hline 26. & Teacher should not negatively criticize students who make mistakes in class. & & & & & & \\
\hline & Theory into practice & & & & & & \\
\hline 27. & Teacher should orient students to the lesson to be learned. & & & & & & \\
\hline 28. & Teacher should tell students what they will learn and why it is important. & & & & & & \\
\hline 29. & Teacher should model what students are expected to do. & & & & & & \\
\hline 30. & Teacher should check for students' understanding. & & & & & & \\
\hline 31. & $\begin{array}{l}\text { Teacher should give students opportunity for practice under the teacher's } \\
\text { guidance. }\end{array}$ & & & & & & \\
\hline 32. & $\begin{array}{l}\text { Teacher should make assignments that give students chance to practice what } \\
\text { they have learned on their own. }\end{array}$ & & & & & & \\
\hline & Behavior modification & & & & & & \\
\hline 33. & Teacher should begin the lesson by presenting stimulus. & & & & & & \\
\hline 34. & Teacher should observe students' behaviors. & & & & & & \\
\hline 35. & $\begin{array}{l}\text { Appropriate behaviors should be reinforced by the teacher as quickly as } \\
\text { possible. }\end{array}$ & & & & & & \\
\hline
\end{tabular}




\begin{tabular}{|c|c|c|c|c|c|c|c|}
\hline No. & $\begin{array}{l}\text { Strongly Disagree (STD) } \\
\text { Disagree(D) } \\
\text { Slightly Disagree (SLD) }\end{array}$ & $\begin{array}{l}\text { STD } \\
\text { (1) }\end{array}$ & $\begin{array}{c}\text { D } \\
\text { (2) }\end{array}$ & $\begin{array}{l}\text { SLD } \\
\text { (3) }\end{array}$ & $\begin{array}{l}\text { SLA } \\
\text { (4) }\end{array}$ & $\begin{array}{c}\text { A } \\
\text { (5) }\end{array}$ & $\begin{array}{c}\text { STA } \\
\text { (6) }\end{array}$ \\
\hline & \multicolumn{7}{|l|}{ Non-directive teaching } \\
\hline 36. & Teacher should act as a facilitator of learning. & & & & & & \\
\hline 37. & $\begin{array}{l}\text { Teacher should create opportunities for students to increase their self- } \\
\text { understanding and self-concepts. }\end{array}$ & & & & & & \\
\hline 38. & Teacher should involve the students in a teaching-learning partnership. & & & & & & \\
\hline 39. & Teacher should understand students. & & & & & & \\
\hline
\end{tabular}

